\title{
PENGARUH PERSEPSI SISWA TENTANG KETERAMPILAN MENJELASKAN GURU TERHADAP PEMAHAMAN MATERI AKUNTANSI (Studi Kasus Pada Siswa Kelas XI Akuntansi Kompetensi Dasar Mendiskripsikan Pengelolaan Kartu Persediaan Barang di SMK Islam Bustanul Ulum Pakusari Jember Tahun Ajaran 2017/2018)
}

\author{
Westin Mahesti ${ }^{1}$, Sutrisno Djaja ${ }^{1}$, Titin Kartini ${ }^{1}$ \\ ${ }^{1}$ Program Studi Pendidikan Ekonomi, Fakultas Keguruan dan Ilmu Pendidikan Universitas Jember \\ E-mail : westinmahesti08@gmail.com
}

\begin{abstract}
Abstrak
Penelitian ini dilakukan untuk mengetahui pengaruh yang signifikan antara persepsi siswa tentang keterampilan menjelaskan guru terhadap pemahaman materi akuntansi (Studi kasus pada siswa kelas XI Akuntansi kompetensi dasar mendiskripsikan pengelolaan kartu persediaan barang di SMK Islam Bustanul Ulum Pakusari Tahun Ajaran 2017/2018). Metode penentuan lokasi penelitian menggunakan metode purposive area yaitu di SMK Islam Bustanul Ulum Pakusari. Penentuan jumlah responden dalam penelitian ini menggunakan metode populasi yaitu sebanyak 58 responden. Metode pengumpulan data yang digunakan terdiri dari metode: angket, wawancara, dokumen, dan observasi. Uji instrumen data dalam penelitian ini menggunakan uji validitas dan uji reliabilitas. Teknik pengolahan data dalam penelitian ini menggunakan editing, skoring, dan tabulasi. Analisis data yang digunakan adalah analisis inferensial/statistik yaitu dengan menggunakan analisis garis regresi sederhana, analisis varian garis regresi, uji $\mathrm{F}$, dan efektivitas garis regresi. Hasil penelitian menunjukkan bahwa ada pengaruh yang signifikan variabel persepsi siswa tentang keterampilan menjelaskan guru terhadap pemahaman materi akuntansi (Studi kasus pada siswa kelas XI Akuntansi kompetensi dasar mendiskripsikan pengelolaan kartu persediaan barang di SMK Islam Bustanul Ulum Pakusari Tahun Ajaran 2017/2018) yang dapat dilihat dari besarnya $F_{\text {hitung }}=243,826>F_{\text {tabel }}=4,013$ dengan tingkat signifikansi $\mathrm{F}=0,000<a=0,05$. Besarnya persentase persepsi siswa tentang keterampilan menjelaskan guru terhadap pemahaman materi akuntansi sebesar $81,3 \%$. sedangkan sisanya yaitu $18,7 \%$ dipengaruhi variabel bebas lainnya yang tidak diteliti, yaitu sikap menghargai terhadap siswa pada saat pembelajaran berlangsung.
\end{abstract}

Kata Kunci: Persepsi Siswa Tentang Keterampilan Menjelaskan Guru dan Pemahaman Materi Akuntansi

\section{PENDAHULUAN}

Guru dalam suatu proses pembelajaran mempunyai tugas untuk mendorong, membimbing dan memberi fasilitas belajar bagi siswa untuk mencapai tujuan pembelajaran, maka dari itu guru seharusnya memiliki kemampuan untuk melakukan interaksi pembelajaran yang baik. Guru juga mempunyai tanggung jawab untuk melihat segala sesuatu yang terjadi dalam kelas untuk membantu proses perkembangan siswa. Di dalam suatu proses pembelajaran, guru di tuntut untuk menciptakan suasana pembelajaran yang aktif, inovatif, kreatif dan menyenangkan. Pemilihan keterampilan dalam menyampaikan materi juga perlu di lakukan oleh guru, agar pembelajaran dapat berlangsung secara baik. Maka dari itu dalam suatu pembelajaran guru diharuskan memiliki keterampilan dalam menjelaskan.

Keterampilan menjelaskan merupakan suatu kegiatan yang dilakukan oleh seorang guru sebagai upaya untuk memberikan pemahaman maupun pengetahuan kepada siswa. Menurut Rachmah (2015:74) keterampilan menjelaskan adalah memberikan penjelasan dan penyajian informasi lisan yang diorganisasikan secara sistematis oleh guru dengan tujuan, misalnya untuk menunjukkan adanya hubungan sebab akibat atau antara yang diketahui dengan yang tidak diketahui atau antara hukum yang berlaku umum dengan bukti atau contoh sehari- hari.

Dalam pembelajaran sangat mustahil jika keterampilan menjelaskan ini tidak dikuasai oleh seorang guru. Melalui keterampilan ini maka siswa akan banyak menerima informasi, ide, dan pengetahuan baru yang dijelaskan oleh guru dan tingkat keberhasilan guru diketahui melalui tingkat pemahaman yang ditunjukan oleh siswa pada materi tertentu. Ciri utama keterampilan penjelasan yaitu penyampaian informasi yang terencana dengan baik, disajikan dengan benar, serta urutan yang cocok (Asril, 2013:84).

SMK Islam Bustanul Ulum Pakusari Jember, merupakan sekolah yang pada umumnya guru menyampaikan pembelajaran masih menggunakan keterampilan menjelaskan, salah satu faktor yang mempengaruhi pemahaman siswa ialah persepsi siswa pada keterampilan menjelaskan guru, karena paham atau tidaknya siswa pada materi dapat di lihat dari proses guru dalam menjelaskan. Marno dan Idris (2016:105) mutu pelaksanaan menjelaskan dapat ditingkatkan dengan memerhatikan unsur- unsur atau komponen- komponen 
keterampilan menjelaskan meliputi; orientasi/pengarahan, kalimat yang sederhana, penggunaan contoh/ilustrasi, struktur/sistematis, variasi, dan balikan (FIeedback).

Persepsi Siswa merupakan suatu proses untuk menggabungkan dan mengorganisasi suatu data melalui alat indera mengenai hal yang ada di sekeliling mereka. Menurut Walgito (2010:99) persepsi merupakan suatu proses yang didahului oleh proses penginderaan, yaitu merupakan proses diterimanya stimulus oleh individu melalui indera atau juga disebut proses sensoris. Ketika guru menjelaskan suatu materi, siswa pasti dapat menimbulkan persepsi pada keterampilan guru di dalam menjelaskan. Siswa dapat mempersepsikan cara guru dalam menjelaskan, apakah guru meggunakan bahasa yang jelas, suara yang mudah dipahami, terstruktur, menggunakan contoh, memberikan penekanan pada materi yang penting, menarik dan memberikan balikan ataupun memberi waktu kepada siswa untuk bertaya tentang materi yang belum dipahami oleh siswa. Sehingga sangat penting bagi seorang guru menerapkan keterampilan menjelaskan dengan baik agar persepsi siswa terhadap guru positif dan dapat meningkatkan pemahaman siswa.

Pemahaman merupakan salah satu aspek kognitif yang termasuk dalam tingkat pemahaman (C2) berdasarkan taksonomi bloom. Siswa diharapkan dapat mengembangkan aspek kognitif yang tidak hanya untuk mengetahui atau mengingat materi pelajaran tapi siswa juga harus lebih memahami materi pelajaran yang disampaikan oleh guru. Pemahaman materi dapat diartikan sebagai suatu proses, perbuatan, cara untuk mengerti dan mengetahui dengan benar. Pemahaman atau komprehensi adalah tingkat kemampuan yang mengharapkan testee mampu memahami arti atau konsep, situasi, serta fakta yang diketahuinya (Purwanto, 2012 : 44).

Pemahaman siswa merupakan salah satu dari aspek kognitif, siswa harus dapat memahami konsep dan bahan pelajaran yang diberikan oleh guru sehingga siswa dapat menjelaskan suatu konsep dengan bahasanya sendiri, namun pengertiannya tidak jauh dari apa yang telah dijelaskan oleh gurunya. Adapun beberapa cara yang digunakan untuk mengetahui tingkat pemahaman siswa yaitu dengan memberikan tes kepada siswa untuk mengetahui sejauh mana tingkat pemahaman siswa terhadap materi pelajaran yang telah diberikan oleh guru. Pemahaman siswa sangat penting karena dapat mempengaruhi hasil belajar siswa, siswa yang memahami materi pelajaran sudah pasti ia akan dapat menyelesaikan soal tes materi akuntansi yang diberikan oleh guru pada kompetensi dasar mendiskripsikan pengelolaan kartu persediaan.

Berdasarkan observasi awal, yang dilakukan di SMK Islam Bustanul Ulum Pakusari masih terdapat guru yang kurang mengerti dengan keterampilan mengajar yang digunakan. Dilihat dari proses pembelajaran ada beberapa siswa yang tidak memperhatikan dengan baik dan siswa kurang aktif ketika proses pembelajaran akuntansi, sehingga membuat aktivitas belajar di dalam kelas rendah. Selain itu persepsi siswa tentang keterampilan menjelaskan guru dapat berpengaruh terhadap pemahaman siswa, di lihat dari siswa belum bisa menjelaskan kembali materi yang telah disampaikan oleh guru, siswa belum bisa memberikan contoh lain selain contoh yang di contohkan oleh guru di depan kelas dan siswa belum bisa mengerjakan soal - soal lain apabila soal itu di ganti atau soal itu berubah.

Mengacu penjelasan di atas, maka dapat diambil suatu hipotesis penelitian yang dapat digunakan sebagai dasar dilakukannya penelitian ini yaitu: "ada pengaruh yang signifikan antara persepsi siswa tentang keterampilan menjelaskan guru terhadap pemahaman materi Akutansi kelas XI SMK Islam Bustanul Ulum Pakusari pada kompetensi dasar mendiskripsikan pengelolaan kartu persediaan barang".

\section{METODE}

Penelitian ini merupakan penelitian kuantitatif, yaitu untuk mengetahui pengaruh persepsi siswa tentang keterampilan menjelaskan guru terhadap pemahaman materi akuntansi (Studi kasus pada siswa kelas XI Akuntansi kompetensi dasar mendiskripsikan pengelolaan kartu persediaan barang di SMK Islam Bustanul Ulum Pakusari Tahun Ajaran 2017/2018). Metode penentuan lokasi penelitian menggunakan metode purposive area yaitu SMK Islam Bustanul Ulum Pakusari yang beralamat Jl. Himalaya No. 17, RT/RW 3/7, Dsn. Rowo, Ds./Kel Pakusari, Kec. Pakusari, Kab. Jember, Prop. Jawa Timur. Penentuan jumlah responden dalam penelitian ini menggunakan metode populasi yaitu sebanyak 58 responden. Metode pengumpulan data yang digunakan terdiri dari metode: angket, wawancara, dokumen, dan observasi. Uji instrumen data dalam penelitian ini menggunakan uji validitas dan uji reliabilitas. Teknik pengolahan data dalam penelitian ini menggunakan editing, skoring, dan tabulasi. Analisis data yang digunakan adalah analisis inferensial/statistik yaitu dengan menggunakan analisis garis regresi sederhana dengan rumus sebagai berikut:

$$
\hat{\mathrm{Y}}=\mathrm{a}+\mathrm{bX}
$$

Untuk analisis varian garis regresi yaitu untuk mengetahui kuat tidaknya atau tingkat keeratan variabel persepsi siswa tentang keterampilan menjelaskan guru terhadap pemahaman materi akuntansi (Studi kasus pada siswa kelas XI Akuntansi kompetensi dasar mendiskripsikan pengelolaan kartu persediaan barang di SMK Islam Bustanul Ulum Pakusari Tahun Ajaran 2017/2018) yaitu dengan rumus sebagai berikut: 


$$
\mathrm{Ry}=\sqrt{\frac{a \sum X Y}{\sum Y^{2}}}
$$

Sedangkan uji $\mathrm{F}$ yaitu untuk mengetahui pengaruh yang signifikan variabel persepsi siswa tentang keterampilan menjelaskan guru terhadap pemahaman materi akuntansi (Studi kasus pada siswa kelas XI Akuntansi kompetensi dasar mendiskripsikan pengelolaan kartu persediaan barang di SMK Islam Bustanul Ulum Pakusari Tahun Ajaran 2017/2018) dengan rumus sebagai berikut:

$$
F_{\text {reg }}=\frac{R_{y}^{2}(N-m-1)}{m\left(1-R_{y}^{2}(1)\right.}
$$

Selanjutnya, untuk uji efektivitas garis regresi yaitu untuk mengetahui berapa besar (\%) pengaruh variabel persepsi siswa tentang keterampilan menjelaskan guru terhadap pemahaman materi akuntansi (Studi kasus pada siswa kelas XI Akuntansi kompetensi dasar mendiskripsikan pengelolaan kartu persediaan barang di SMK Islam Bustanul Ulum Pakusari Tahun Ajaran 2017/2018).

\section{HASIL DAN PEMBAHASAN}

\section{Hasil Penelitian}

Berdasarkan hasil analisis inferensial yaitu analisis garis regresi sederhana diperoleh $\mathbf{R}_{\text {square }}$ sebesar 0,813 . Koefisien determinasi $\mathbf{R}_{\text {square }}$ dalam penelitian ini digunakan untuk mengukur besarnya pengaruh variabel bebas $(\mathrm{X})$ dan variabel terikat $(\mathrm{Y})$. Jenis analisis ini digunakan untuk mengetahui pengaruh yang signifikan dari variabel bebas yaitu variabel persepsi siswa tentang keterampilan menjelaskan guru terhadap pemahaman materi akuntansi (Studi kasus pada siswa kelas XI Akuntansi kompetensi dasar mendiskripsikan pengelolaan kartu persediaan barang di SMK Islam Bustanul Ulum Pakusari Tahun Ajaran 2017/2018). Berdasarkan analisis data yang dilakukan diperoleh hasil dalam tabel berikut ini:

Tabel Ringkasan Uji F, Multiple R, dan R Square

\begin{tabular}{ccccccc}
\hline Variabel & F Hitung & $\mathrm{F}_{\text {Tabel }}$ & Sig. F & $a$ & $\mathrm{R}$ & $\mathrm{R}_{\text {Square }}$ \\
\hline X terhadap Y & 243,826 & 4,013 & 0,000 & 0,05 & $0,902^{\mathrm{a}}$ & 0,813 \\
\hline Sumber : Data diolah 2018 & & & & &
\end{tabular}

Tabel di atas menunjukkan bahwa $\mathrm{F}_{\text {hitung }}=243,826>\mathrm{F}_{\text {tabel }}=4,013$ dengan tingkat signifikansi $\mathrm{F}=0,000$ $<a=0,05$. Hal ini menunjukkan bahwa variabel persepsi siswa tentang keterampilan menjelaskan guru memiliki pengaruh yang signifikan terhadap pemahaman materi akuntansi (Studi kasus pada siswa kelas XI Akuntansi kompetensi dasar mendiskripsikan pengelolaan kartu persediaan barang di SMK Islam Bustanul Ulum Pakusari Tahun Ajaran 2017/2018). Untuk koefisien determinasi $\mathrm{R}_{\text {Square }}$ sebesar 0,813, yang dengan proporsi sumbangan variabel X terhadap Y sebesar $81,3 \%$, sedangkan sisanya yaitu $18,7 \%$ dipengaruhi variabel bebas lainnya yang tidak diteliti, yaitu sikap menghargai terhadap siswa pada saat pembelajaran berlangsung.

\section{Pembahasan}

Implikasi dari penelitian ini adalah jika persepsi siswa tentang keterampilan mengajar guru positif, maka kemampuan siswa untuk menyerap materi pelajaran akan optimal yang selanjutkan akan menjadikan hasil belajar menjadi baik. Sebaliknya, jika persepsi siswa tentang keterampilan mengajar guru negatif, maka siswa akan kesulitan dalam menyerap materi pelajaran yang diberikan sehingga akan berpengaruh langsung terhadap hasil belajar siwa yang rendah atau kurang optimal. Di dalam suatu proses pembelajaran, guru di tuntut untuk menciptakan suasana pembelajaran yang aktif, inovatif, kreatif dan menyenangkan. Pemilihan keterampilan dalam menyampaikan materi juga perlu di lakukan oleh guru, agar pembelajaran dapat berlangsung secara baik. Maka dari itu dalam suatu pembelajaran guru diharuskan memiliki keterampilan dalam menjelaskan.

Penelitian ini dilakukan untuk mengetahui pengaruh persepsi siswa tentang keterampilan menjelaskan guru terhadap pemahaman materi akuntansi (studi kasus pada siswa kelas XI akuntansi kompetensi dasar mendiskripsikan pengelolaan kartu persediaan barang di SMK Islam Bustanul UlumPakusari tahun ajaran 2017/2018). Hipotesis yang menyatakan bahwa ada pengaruh yang signifikan antara persepsi siswa tentang keterampilan menjelaskan guru terhadap pemahaman materi Akutansi kelas XI SMK Islam Bustanul Ulum Pakusari pada kompetensi dasar mendiskripsikan pengelolaan kartu persediaan barang diterima atau mempunyai pengaruh positif yang signifikan. Hal ini artinya hipotesis tersebut terjawab secara simultan persepsi siswa tentang keterampilan menjelaskan guru berpengaruh terhadap pemahaman materi akuntansi sebesar 81,3\%.

Berdasarkan hasil penelitian uji $\mathrm{F}$, dapat diketahui bahwa ada pengaruh persepsi siswa tentang keterampilan menjelaskan guru terhadap pemahaman materi akuntansi (studi kasus pada siswa kelas XI akuntansi kompetensi dasar mendiskripsikan pengelolaan kartu persediaan barang di SMK Islam Bustanul UlumPakusari 
tahun ajaran 2017/2018) secara signifikan. Nilai $F_{\text {hitung }}=243,826>F_{\text {tabel }}=4,013$ dengan tingkat signifikansi $F=$ $0,000<a=0,05$, berarti variabel persepsi siswa tentang keterampilan menjelaskan guru memiliki pengaruh yang signifikan terhadap pemahaman materi akuntansi (studi kasus pada siswa kelas XI akuntansi kompetensi dasar mendiskripsikan pengelolaan kartu persediaan barang di SMK Islam Bustanul UlumPakusari tahun ajaran 2017/2018), maka keputusan yang diambil adalah hipotesis diterima.

Berdasarkan penelitian yang telah dilakukan dapat diketahui bahwa ketika menjelaskan materi yaitu mendiskripsikan pengelolaan kartu persediaan barang guru menggunakan suara yang dapat didengar seluruh siswa dan bahasa yang mudah dipahami oleh siswanya. Selain itu pada saat menjelaskan materi akuntansi disesuaikan dengan materi yang mudah ke materi yang sulit dipahami siswa dan dimulai dari materi yang sudah diketahui olehsiswa ke materi yang belum diketahui oleh siswa. Memberikan contoh pada materi akuntansi seperti menggunakan transaksi-transaksi yang biasa dilakukan siswa dalam kehidupan sehari-hari bertujuan agar siswa lebih mudah untuk memahami materi dan contoh yang diberikan sesuai dengan kenyataan dan berkaitan dengan kehidupan sehari- hari siswa.

Ketika menjelaskan pada saat terdapat materi yang penting juga harus diberikan penekanan sehingga membantu siswa untuk dapat memahami dan mengingat materi akuntansi. Guru memberikan humor namun berkaitan dengan materi agar kondisi pembelajaran tidak membosankan sehingga siswa dapat memahami materi yang diberikan guru. Pada akhir menjelaskan guru selalu memberikan kesempatan kepada siswa untuk bertanya tentang materi yang belum dipahami oleh siswanya.

Berikut merupakan hasil wawancara yang dilakukan oleh peneliti dengan dengan siswa XI SMK Islam Bustanul Ulum Pakusari yang menjadi responden dalam penelitian ini.

“........................... guru selalu menjelaskan materi secara rinci bahkan guru sering mengulang

dalam menjelaskan materi jika ada siswa yang merasa kesulitan dalam memahami materi akuntansi yang dijelaskan guru tersebut" (DI, $16^{\mathrm{Th}}$ ).

Berdasarkan hasil wawancara tersebut dapat diketahui bahwa, dalam menjelaskan materi akuntansi, guru senantiasa menjelaskan secara rinci serta memperhatikan tingkat kemampuan siswa dalam memahami materi yang dijelaskan guru tersebut. Guru akan senantiasa mengulang penjelasan materi jika dirasa ada siswa yang masih belum memahami materi yang dijelaskan tersebut. Keterampilan menjelaskan guru di dalam kelas tersebut dapat dipersepsikan oleh siswa, karena persepsi Siswa merupakan suatu proses untuk menggabungkan dan mengorganisasi suatu data melalui alat indera mengenai hal yang ada di sekeliling mereka.

Guru merupakan faktor yang mempengaruhi berhasil tidaknya proses belajar dan karenanya guru harus menguasai prinsip- prinsip belajar di samping meguasai materi yang diajarkan (Hamalik, 2015:33). Siswa dapat mempersepsikan cara guru dalam menjelaskan materi akuntansi karena ketika pembelajaran berlangsung siswa dapat mempersepsikan bagaimana cara guru dalam menjelaskan, apakah jelas dengan meggunakan bahasa dan suara yang mudah dipahami dan didengar oleh siswa, terstruktur, menggunakan contoh, memberikan penekanan pada materi yang penting, menarik dan memberikan balikan ataupun memberi waktu kepada siswa untuk bertanya tentang materi yang belum dipahami oleh siswa. Adapun indikator persepsi siswa tentang keterampilan menjelaskan guru meliputi jelas (Clarity), terstruktur/sistematis, penggunaan contoh atau ilustrasi, penekanan,menarik balikan (Feedback).

Orientasi/pengarahan, yaitu dengan memberi orientasi berarti mengantarkan siswa pada pokok persoalan yang akan dibahas yaitu materi mendiskripsikan pengelolaan kartu persediaan barang dan 'menempatkan' informasi/ penjelasan yang akan disampaikan itu dalam suatu kerangka yang lebih luas dan sesudah pelajaran berakhir,guru memberikan kisi - kisi mata pelajaran yang akan dibahas di materi selanjutnya agar siswa dapat belajar di rumah. Tujuannya agar siswa mampu mengingat kembali apa yang di ajarkan oleh guru pada materi sebelumnya, dengan cara guru mengulas kembali materi yang sudah diajarkan dengan memberikan tanya jawab pada siswa. Berdasarkan angket yang disebar kepada responden penelitian dapat diketahui bahwa sebagian siswa siswa XI SMK Islam Bustanul Ulum Pakusari yang menjadi responden dalam penelitian ini menjawab bahwa penilaian siswa terhadap pengulasan materi akuntansi yang ditanyakan guru sebelum pelajaran berlangsung sangat baik, karena dapat lebih memahami materi dan penilaian siswa saat guru memberikan kisi - kisi materi selanjutnya sangat penting, karena dapat fokus belajar pada materi yang terdapat pada kisi - kisi.

Indikator selanjutnya yaitu kalimat yang sederhana, suatu kalimat disebut sebagai kalimat sederhana karena berkaitan dengan pola kalimat yang masih mendasar dengan pola kalimat yang terdiri dari subyek dan predikat. Hal ini dilakukan agar siswa mampu memahami dengan baik materi yang disampaikan oleh guru. Berdasarkan angket yang disebar kepada responden penelitian dapat diketahui bahwa sebagian siswa siswa XI SMK Islam Bustanul Ulum Pakusari yang menjadi responden dalam penelitian ini menjawab bahwa peta konsep yang dijelaskan oleh guru kepada siswa sangat jelas, karena sudah lengkap dengan penjelasan yang rinci dan runtutan materi yang dijelaskan dengan peta konsep sangat runtun, karena guru menjelaskan sesuai dengan alur yang ada di peta konsep dengan penjelasan rinci. 
Penggunaan contoh/ilustrasi, Pemahaman siswa terhadap prinsip/dalil/hukum dapat ditingkatkan dengan menghubungkan pada kejadian sehari-hari atau kegiatan yang sering dijumpai siswa. Guru harus memberikan contoh-contoh secara nyata, konkret,jelas sesuai daya tangkap dan linkungan siswa, Guru memberikan contoh secara langsung yang ada do sekitar siswa agar siswa lebih memahami materi akuntansi yang di sampaikan oleh guru. Berdasarkan angket yang disebar kepada responden penelitian dapat diketahui bahwa sebagian siswa siswa XI SMK Islam Bustanul Ulum Pakusari yang menjadi responden dalam penelitian ini menjawab bahwa ilustrasi yang diterapkan guru berkaitan dengan materi yang sedang dijelaskan sangat menarik,karena ilustrasi yang digunakan sangat cocok dan mudah di pahami dan ilustrasi yang diterapkan oleh guru sudah sesuai dengan pengetahuan siswa.

Indikator selanjutnya yaitu struktur/sistematis. Agar penjelasan guru mudah dipahami siswa, hendaknya tata susunan atau urutan langkah-langkah atau jalan pikiran ditunjukan dengan jelas selain itu menggunakan peta konsep diperlukan untuk menjelaskan materi, sehingga siswa dapat dengan mudah membedakan mana yang pokok dan mana yang bukan. Jadi guru menjelaskan materi akuntansi sesuai dengan urutan yang akan dipelajari. Berdasarkan angket yang disebar kepada responden penelitian dapat diketahui bahwa sebagian siswa siswa XI SMK Islam Bustanul Ulum Pakusari yang menjadi responden dalam penelitian ini menjawab bahwa kalimat yang digunakan oleh guru dalam menjelaskan materi sangat jelas, karena bahasa yang digunakan guru sangat mudah dipahami siswa dan guru selalu menggunakan bahasa sehari hari dalam penyampaian materi akuntasi.

Selanjutnya yaitu variasi, bila pelajaran hanya berisikan uraian dan penjelasan-penjelasan, kemungkinan besar siswa segera berkurang minatnya. Oleh karena itu, guru harus pandai memikat perhatian siswa. Keterampilan menjelaskan tidak berarti guru terlalu serius sepanjang jam pelajaran: perlu juga diselingi informasi lain yang ringan dan lucu. Berdasarkan angket yang disebar kepada responden penelitian dapat diketahui bahwa sebagian siswa siswa XI SMK Islam Bustanul Ulum Pakusari yang menjadi responden dalam penelitian ini menjawab bahwa variasi pembelajaran yang digunakan oleh guru sangat sesuai, karena banyak variasi yang guru terapkan dan penilaian siswa tentang variasi pembelajaran yang dilakukan oleh guru sangat menarik, karena guru menggunakan strategi pembelajaran yang berbeda dan cocok di terapkan.

Dan yang terakhir yaitu balikan (Feedback), Dalam menyajikan penjelasan, guru hendaknya tidak hanya bicara sendiri saja (monolog), melainkan juga memberi kesempatan kepada siswa untuk menunjukkan pengertiaanya atau ketidak mengertiaanya. Guru sebelum menutup pelajaran hendaknya memberikan sesi tanya jawab mengenai materi yang telah di sampaikan tadi. Berdasarkan angket yang disebar kepada responden penelitian dapat diketahui bahwa sebagian siswa siswa XI SMK Islam Bustanul Ulum Pakusari yang menjadi responden dalam penelitian ini menjawab bahwa guru selalu memberikan kesempatan kepada siswa untuk bertanya tentang materi akuntansi yang telah dijelaskan.

Persepsi siswa dapat memberikan dampak pada pemahaman siswa terhadap materi akuntansi. Siswa diharapkan dapat mengembangkan aspek kognitif yang tidak hanya untuk mengetahui atau mengingat materi pelajaran tapi siswa juga harus lebih memahami materi pelajaran yang disampaikan oleh guru. Adapun beberapa cara yang digunakan untuk mengetahui tingkat pemahaman siswa yaitu dengan memberikan tes kepada siswa untuk mengetahui sejauh mana tingkat pemahaman siswa terhadap materi pelajaran yang telah diberikan oleh guru. Sesuai dengan pendapat Arikunto (2015: 131) pemahaman (comprehension) adalah dengan pemahaman, siswa diminta untuk membuktikan bahwa ia memahami hubungan yang sederhana diantara fakta- fakta atau konsep.

Pemahaman materi dapat diartikan sebagai suatu proses, perbuatan, cara untuk mengerti dan mengetahui dengan benar. Pemahaman atau komprehensi adalah tingkat kemampuan yang mengharapkan testee mampu memahami arti atau konsep, situasi, serta fakta yang diketahuinya. Adapun indator pemahaman materi akutansi yaitu meliputi menjelaskan dan menguraikan.

Berdasarkan angket yang disebar kepada responden penelitian dapat diketahui bahwa sebagian siswa siswa XI SMK Islam Bustanul Ulum Pakusari yang menjadi responden dalam penelitian ini menjawab bahwa setelah di jelaskan oleh guru apakah siswa dapat memahami materi dengan baik karena guru menyampaikan materi dengan bahasa yang jelas dan mudah di mengerti, setelah di jelaskan oleh guru siswa dapat menjelaskan kembali materi di depan kelas, siswa mampu menguraikan soal-soal transaksi ke dalam dokumen, dan siswa mampu mengerjakan soal-soal terkait dengan persediaan barang dagang.

Dari penjelasan tersebut nampak jelas bahwa persepsi siswa tentang keterampilan menjelaskan guru berpengaruh terhadap pemahaman materi akuntansi (studi kasus pada siswa kelas XI akuntansi kompetensi dasar mendiskripsikan pengelolaan kartu persediaan barang di SMK Islam Bustanul UlumPakusari tahun ajaran 2017/2018). Keterampilan menjelaskan merupakan suatu penjelasan seorang guru kepada siswanya yang memiliki tujuan yaitu agar siswa dapat memahami materi pelajaran yang disampaikan. Hal ini juga diperkuat oleh (Rasto, 2015:60) penjelasan yang bersifat sederhana dan kompleks semuanya bermuara pada tujuan yang sama yaitu mendapatkan pemahaman siswa.

Berikut merupakan hasil wawancara yang dilakukan oleh peneliti dengan dengan siswa XI SMK Islam 
Bustanul Ulum Pakusari yang menjadi responden dalam penelitian ini.

“......................... Tentu saja ada pengaruh antara pengaruh keterampilan menjelaskan yang dilakukan oleh guru terhadap pemahaman materi akuntansi yang dijelaskan tersebut mbak, karena dengan kemampuan siswa dalam memberikan tanggapan terhadap cara menjelaskan guru seperti kejelasan, sistematis, penggunaan contoh, penekanan, menarik dan balikan pada saat guru melakukan penjelasan materi akuntansi tersebut yang akan dapat mendorong siswa untuk memahami materi yang disampaikan oleh seorang guru tersebut mbak, dan juga dapat memberikan koreksi kepada guru untuk lebih baik dalam melaksanakan kegiatan pembelajaran mbak." (DI, $\left.16^{\mathrm{Th}}\right)$.

Berdasarkan hasil wawancara tersebut dapat diketahui bahwa ada pengaruh antara pengaruh keterampilan menjelaskan yang dilakukan oleh guru terhadap pemahaman materi akuntansi yang dijelaskan tersebut, karena dengan kemampuan siswa dalam memberikan tanggapan terhadap cara menjelaskan guru seperti kejelasan, sistematis, penggunaan contoh, penekanan, menarik dan balikan pada saat guru melakukan penjelasan materi akuntansi tersebut yang akan dapat mendorong siswa untuk memahami materi yang disampaikan oleh seorang guru tersebut, dan juga dapat memberikan koreksi kepada guru untuk lebih baik dalam melaksanakan kegiatan pembelajaran. Hal ini sesuai dengan pendapat Mohan, R (dalam Rasto, 2015:55) keterampilan menjelaskan bertujuan memastikan bahwa penjelasan tersebut dipahami siswa. Agar siswa dapat memahami selanjutnya dapat mengaplikasikan penjelasan guru dalam bentuk tes belajar siswa. Beberapa komponen keterampilan menjelaskan yang dapat dikuasai guru yaitu jelas, terstruktur/sistematis, Penggunaan contoh, penekanan, menarik, balikan.

Menurut Mohan,R (dalam Rasto, 2015:55) menjelaskan merupakan suatu kegiatan untuk memberikan pemahaman tentang konsep dan prinsip. Keterampilan menjelaskan bertujuan memastikan bahwa penjelasan tersebut dipahami siswa. Guru akan mengulang penjelasan dari materi akuntasi tersebut jika dirasa ada siswa yang masih belum paham terhadap materi yang dijelaskan tersebut. Hal ini nampak jelas bahwa guru bertanggung jawab atas keberhasilan pembelajaran. Guru harus dapat menjelaskan dan memberikan pemahaman berkaitan dengan materi yang diajarkan (Rachmah,S 2016:76). Hal ini merupakan sesuatu yang sangat penting terutama pada mata pelajaran akuntansi yang dirasa siswa cukup sulit dalam memahami materinya. Oleh karena itulah guru harus dapat menjelaskan materi secara jelas dan mudah dipahami oleh siswa.

Berdasarkan pemaparan di atas dapat disimpulkan bahwa variabel persepsi siswa tentang keterampilan menjelaskan guru merupakan salah satu faktor yang mempengaruhi pemahaman materi akuntansi (studi kasus pada siswa kelas XI akuntansi kompetensi dasar mendiskripsikan pengelolaan kartu persediaan barang di SMK Islam Bustanul UlumPakusari tahun ajaran 2017/2018). Berdasarkan hasil penelitian dan pembahasan dalam penelitian ini membuktikan bahwa hipotesis dalam penelitian ini diterima yaitu ada pengaruh yang signifikan antara persepsi siswa tentang keterampilan menjelaskan guru terhadap pemahaman materi Akutansi kelas XI SMK Islam Bustanul Ulum Pakusari pada kompetensi dasar mendiskripsikan pengelolaan kartu persediaan barang.

\section{PENUTUP \\ Kesimpulan}

Berdasarkan analisis data dan hasil pembahasan penelitian yang telah diuraikan pada bab sebelumnya, maka dapat disimpulkan bahwa ada pengaruh yang signifikan persepsi siswa tentang keterampilan menjelaskan guru terhadap pemahaman materi akuntansi sebesar $81,3 \%$. Sedangkan sisanya yaitu $18,7 \%$ dipengaruhi variabel bebas lainnya yang tidak diteliti dalam penelitian ini. Hasil penelitian menunjukkan bahwa persepsi siswa tentang keterampilan menjelaskan guru sangat baik yaitu siswa mampu memberikan tanggapan terhadap cara menjelaskan guru seperti kejelasan, sistematis, penggunaan contoh, penekanan, menarik dan balikan pada saat guru melakukan penjelasan materi dengan baik, sehingga kemampuan siswa dalam memahami materi akuntansi sangat baik.

\section{Saran}

Berdasarkan kesimpulan di atas dari penelitian ini, maka peneliti ingin memberikan saran yaitu bagi guru di SMK Islam Bustanul Ulum Pakusari, sebaiknya dalam memberikan materi kepada siswa menggunakan kalimat yang sederhana supaya siswa lebih mudah mengerti pada materi yang di sampaikan. Bagi siswa, hendaknya lebih giat dalam belajar, lebih meningkatkan perhatian ketika guru menjelaskan, serta lebih kritis terhadap penjelasan guru. Dan bagi peneliti lain, diharapkan bagi peneliti lain yang akan melakukan penelitian serupa dengan penelitian ini untuk mengambil variabel lain yang tidak turut diteliti dalam penelitian ini, supaya dapat menciptakan penelitian-penelitian yang lebih baik dan nantinya sebagai tambahan referensi penelitian yang sejenis. 


\section{DAFTAR PUSTAKA}

Arikunto, S. 2015. Dasar-Dasar Evaluasi Pendidikan Edisi 2. Jakarta :Bumi Aksara

Asril, Z. 2013. Micro Teaching disertai pedoman lapangan. Jakarta: PT. RajaGrafindo Persada

Hamalik, O. 2015. Psikologi Belajar dan Mengajar.Jakarta : Sinar Baru Algasindo

Marno dan Idris. 2016. Strategi dan Metode Pengajaran: Menciptakan Keterampilan Mengajar yang Efektif dan Edukatif

Purwanto, N. 2012. Teknik - Teknik Evaluasi Pengajaran.Bandung : Remaja Rosdakarya Offset

Rachmah, S. 2015. Micro Teaching Pengembangan Keterampilan Mengajar.Yogyakarta : Kaukaba Dipantara.

Rasto. 2015. Pembelajaran Mikro Mengembangkan Keterampilan Mengajar Guru Profesional.Bandung : Alfabeta

Walgito, B. 2010. Pengantar Psikologi Umum. yogyakarta: Andi yogyakarta. 